\title{
Routine K/Ar age determination on post-Silurian dolerite dykes, North Greenland fold belt
}

\author{
P. R. Dawes, D. C. Rex and N. J. Soper
}

This note documents results of routine $\mathrm{K} / \mathrm{Ar}$ isotopic age determination of dolerite dykes from the North Greenland fold belt. All the material was collected in 1969 by two of us (P.R.D. and N.J.S.) during the Joint Services Expedition to Peary Land; the isotopic analyses have been undertaken by D.C.R. in the geological laboratories of the University of Leeds. In view of the renewed interest in the tectonic and magmatic history of the Peary Land region stemming from the systematic field studies carried out by GGU in 1978-1980 (see GGU Rapport 88, 99 and 106), the results of this early dating programme are listed here as a contribution to this discussion. Recently, some reference has been made in the literature to these hitherto unpublished results (Dawes \& Soper, 1979; Higgins et al., 1981; Håkansson \& Pedersen, 1982).

\section{Geological setting}

The North Greenland fold belt is traversed by dolerite dykes of various trends, and some dykes are present to the south of the fold belt cutting the Proterozoic to Silurian platform strata. In the fold belt the dykes cut the folded Lower Palaeozoic strata that were deformed and metamorphosed in mid-Palaeozoic time. Some dykes, particularly in the northern coastal area, show the effect of important post-intrusion deformation attributed to late Phanerozoic (Cretaceous-Tertiary) regional reactivation (Dawes \& Soper, 1979; Higgins et al., 1981).

The only hitherto published isotopic age dates on Phanerozoic basic dykes from North Greenland are a K/Ar age of $66 \mathrm{Ma}$ on an E-W trending dyke from the southern margin of the fold belt (Dawes \& Soper, 1971), and a K/Ar age of 72 Ma on a NW-trending dyke from the platform (Henriksen \& Jepsen, 1970). The study reported here was a first attempt through a regional isotopic study to corroborate the suggested late Cretaceous intrusion event. It should be stressed that the dyke material available, as well as the $\mathrm{K} / \mathrm{Ar}$ method used, were far from ideal for accurate isotopic dating of the intrusion age - the results should be seen as a guide for other isotopic work in the region. All the results obtained during the routine study are listed, irrespective of the degree of geological significance each might imply.

\section{The dyke material}

The eight samples reported here are taken from separate dykes, the locations of which are indicated on fig. 3 . The samples were selected from a larger collection of material as being mineralogically the least altered, as well as covering the widest possible range in dyke trends. The samples were each 1-2 kg in weight and all weathered surfaces were removed prior to analysis.

All the dykes are relatively straight, cross-cutting bodies with planar contacts; the rock 


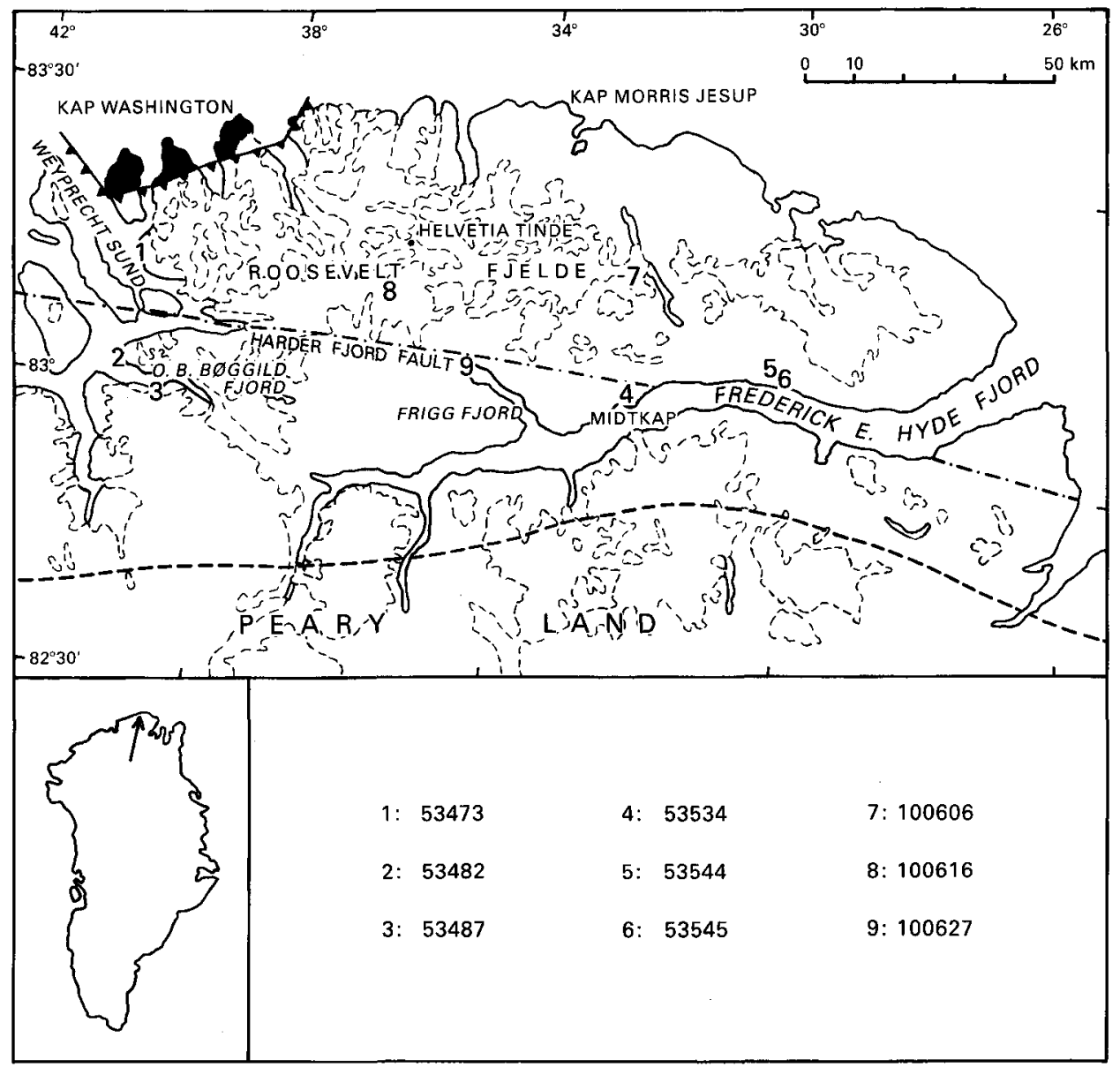

Fig. 3. Sketch map of Johannes V. Jensen Land, Peary Land, showing the location of the dyke samples used in the routine K/Ar study reported on here together with a previously dated dyke (GGU 53487, $66 \mathrm{Ma}$ ). The black area north of the Kap Cannon thrust represents the Kap Washington volcanic Group and the Wandel Sea Basin sediments. The Harder Fjord fault is shown; the dashed line represents the southern boundary of the North Greenland fold belt. The main ice fields are outlined with a broken line.

type is dolerite or olivine dolerite with sub-ophitic texture. The rocks show a varying degree of alteration that is regarded as essentially deuteric; it involved slight to moderate alteration of plagioclase, slight alteration of pyroxene and varying replacement of olivine.

\section{Experimental procedure}

The samples were processed and analysed by the method described by Rex \& Dodson (1970). Potassium was determined by flame photometry in triplicate and the value given in Table 1 is the average of the three measurements. 
Table 1. K/Ar analytical details, major element composition, Sr content and K/Ar age dates of dolerite dykes from the North Greenland fold belt

\begin{tabular}{|c|c|c|c|c|c|c|c|c|c|c|}
\hline $\begin{array}{l}\text { GGU } \\
\text { Sample } \\
\text { No. }\end{array}$ & 53473 & 53482 & 53534 & 53544 & 53545 & 100606 & 100616 & 100627 & $\begin{array}{l}\text { Average } \\
\text { Phan. (1) }\end{array}$ & $\begin{array}{l}\text { Average } \\
\text { Phan. (2) }\end{array}$ \\
\hline 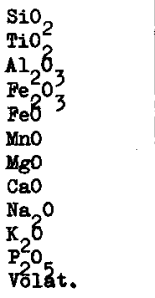 & $\begin{array}{r}45.92 \\
3.79 \\
14.71 \\
1.77 \\
11.15 \\
0.23 \\
5.49 \\
9.62 \\
3.41 \\
0.96 \\
1.23 \\
1.21\end{array}$ & $\begin{array}{r}43.01 \\
3.99 \\
13.84 \\
5.66 \\
8.57 \\
0.22 \\
7.57 \\
8.79 \\
2.56 \\
1.39 \\
1.29 \\
2.82\end{array}$ & $\begin{array}{r}46.07 \\
3.39 \\
13.90 \\
5.61 \\
7.83 \\
0.25 \\
7.55 \\
8.81 \\
2.74 \\
0.46 \\
1.07 \\
2.19\end{array}$ & $\begin{array}{r}45.84 \\
4.17 \\
13.35 \\
4.92 \\
9.04 \\
0.24 \\
5.25 \\
8.93 \\
3.03 \\
1.41 \\
1.10 \\
2.29\end{array}$ & $\begin{array}{r}44.11 \\
4.92 \\
12.68 \\
5.45 \\
9.56 \\
0.24 \\
5.94 \\
9.90 \\
3.24 \\
0.69 \\
1.12 \\
2.09\end{array}$ & $\begin{array}{r}45.66 \\
4.08 \\
14.59 \\
2.72 \\
10.46 \\
0.21 \\
5.39 \\
9.21 \\
3.35 \\
1.30 \\
1.20 \\
1.55\end{array}$ & $\begin{array}{r}48.51 \\
3.44 \\
14.43 \\
2.89 \\
10.02 \\
0.20 \\
5.65 \\
9.38 \\
2.97 \\
1.18 \\
0.52 \\
0.81\end{array}$ & $\begin{array}{r}45.17 \\
4.09 \\
14.14 \\
5.07 \\
8.28 \\
0.21 \\
6.42 \\
9.33 \\
2.99 \\
0.23 \\
1.03 \\
2.84\end{array}$ & $\begin{array}{r}45.54 \\
3.98 \\
13.96 \\
4.26 \\
9.36 \\
0.23 \\
6.16 \\
9.25 \\
3.04 \\
0.95 \\
1.07 \\
1.98\end{array}$ & $\begin{array}{r}45.57 \\
4.10 \\
13.17 \\
4.38 \\
9.90 \\
0.22 \\
5.60 \\
9.01 \\
3.01 \\
1.15 \\
1.09 \\
2.39\end{array}$ \\
\hline Totel & 99.77 & 99.73 & 99.87 & 99.57 & 99.94 & 99.80 & 100.00 & 99.80 & 99.81 & 99.59 \\
\hline Sr ppin. & 662 & 574 & 536 & 514 & 534 & 741 & 408 & 797 & 578 & 448 \\
\hline$\not 6 \mathrm{~K}$ & 0.618 & 1.020 & 0.350 & 1.071 & 0.497 & 0.770 & 0.891 & 0.215 & & \\
\hline$\%{ }^{40}$ Ar rad. & 75.9 & 73.3 & 72.5 & 91.5 & 74.2 & 95.0 & 82.3 & 58.8 & & \\
\hline $\begin{aligned} & \text { Vol. }{ }^{40} \mathrm{Ar} \\
& \mathrm{rad} . \mathrm{sec} / \mathrm{g} \\
& \times 10^{-5}\end{aligned}$ & 0.5062 & 0.3311 & 0.3182 & 1.4295 & 0.2379 & 1.8423 & 0.4615 & 0.2144 & & \\
\hline $\mathrm{K} / \mathrm{Ar}$ age Ma & $199+8$ & $82+3$ & $220+9$ & $314 \pm 12$ & $119 \pm 4$ & $531 \pm 16$ & $130+5$ & $250+10$ & & \\
\hline
\end{tabular}

Major element and Sr analysis by XRF; samples 53473, 53482, 53534, 100606 and 100627 by J.G. Holland, Univ. Durham, U.K., 1972; samples 53544,53545 and 100616 by I. Serensen, GGJ, 1978. K/Ar analysis by D.C. Rex, Univ. Leeds, U.K., 1977. Average analyses: (1) $=8 \mathrm{~K} / \mathrm{Ar}$ dated samples; $(2)=36$ dolerite intrusions reported in Soper et al. (1982, Table 2).

$\lambda_{\beta}=4.72 \times 10^{-10} \mathrm{yr}^{-1} \quad \lambda_{e}=0.584 \times 10^{-10} \mathrm{yr}^{-1}$

$40_{\mathrm{K} / \mathrm{K}}=1.19 \times 10^{-4}$ mole/mole $\mathrm{K}$

The dyke locations and results

GGU 100606: SE side of Sifs Gletscher, eastern

K/Ar age: $\mathbf{5 3 1} \pm 16 \mathrm{Ma}$

Roosevelt Fjelde.

From a $5 \mathrm{~m}+$ wide, NNE-trending dyke that cuts deformed arkosic sediments of the Cambrian Polkorridoren Group of Friderichsen et al. (1982).

GGU 53544: On the hill 'Gråtoppen', north side

K/Ar age: $314 \pm 12$ Ma of Frederick E. Hyde Fjord.

From $\mathrm{a} \sim 4 \mathrm{~m}$ wide NW-trending dyke cutting deformed clastic rocks referred to the Cambrian Polkorridoren Group by Friderichsen et al. (1982).

GGU 100627: NW of Fensal Fig, Frigg Fjord,

K/Ar age: $250 \pm 10$ Ma

Harder Fjord fault zone.

Fine-grained contact of a $\sim 10 \mathrm{~m}$ wide $\mathrm{E}-\mathrm{W}$ trending dyke that cuts folded, fine-grained sandstones of uncertain age. The country rocks are probably referable to the Cambrian 
Polkorridoren Group of Friderichsen et al. (1982), although rocks as young as late Cretaceous (Santonian) have been discovered in the fault zone in this area (Soper et al., 1980; Håkansson \& Pedersen, 1982).

GGU 53534: NNE of Midtkap, Frederick E. Hyde Fjord.

K/Ar age: $220 \pm 9$ Ma

From a $6 \mathrm{~m}+\mathrm{m}$ wide $\mathrm{WNW}$-trending dyke that cuts folded and faulted siltstone and shale of a sequence now referred to the Cambrian Polkorridoren Group (Friderichsen et al, 1982).

GGU 53573: Western of two small islands in

K/Ar age: $199 \pm 8$ Ma Weyprecht Sund.

From a $\sim 8 \mathrm{~m}$ wide, $\mathrm{N}-\mathrm{S}$ trending dyke that cuts pale quartzites referred by Friderichsen et al. (1982) to the Skagen Group of probable late Proterozoic age.

GGU 100616: South of Helvetia Tinde, central

K/Ar age: $130 \pm 5 \mathrm{Ma}$ Roosevelt Fjelde.

From a 20-25 m wide NE-trending dyke cutting sandstones of the Cambrian Polkorridoren Group.

GGU 53545: On the hill 'Gråtoppen', north side

K/Ar age: $119 \pm 4 \mathrm{Ma}$ of Frederick E. Hyde Fjord.

From $\mathrm{a} \sim 10 \mathrm{~m}$ wide NNW-trending dyke; field relations as GGU 53544.

GGU 53582: Kap Holger Danske, O. B. Bøggild

K/Ar age: $82 \pm 3$ Ma Fjord.

From a $\sim 5 \mathrm{~m}$ wide, generally E-W trending dyke that cuts a sequence now referable to the Vølvedal and Amundsen Land Groups of Ordovician age (Friderichsen et al., 1982), and which to the east cuts strata as young as Silurian. A dyke attributed to the same swarm from the southern side of O. B. Bøggild Fjord has given a K/Ar age of $66 \pm 6.6 \mathrm{Ma}$ (Dawes \& Soper, 1971).

\section{Discussion}

The eight samples dated show a wide range in K/Ar whole-rock ages, from $531 \mathrm{Ma}$ (Cambrian) to $82 \mathrm{Ma}$ (Cretaceous). No geological evidence suggests that such a range of age of dolerite dykes exists, and at least one age, GGU 100606, $531 \mathrm{Ma}$, can be immediately disregarded. This dyke (like all the others) cuts complexly folded strata that were deformed in the period between late Silurian and early Carboniferous, that is marked by the regional unconformity at the base of the Wandel Sea Basin sediments. In view of the known limitations of dating by the $\mathrm{K} / \mathrm{Ar}$ method in general, and particularly from regions known to have undergone regional reactivation and post-consolidation disturbances, we regard it as highly probable that the wide age range obtained expresses a fundamental disturbance of the K/Ar isotopic system, rather than reflecting intrusion events.

The only geological dated basic dyke event in the fold belt is of Cretaceous age. Dykes and steeply inclined sheets in the northern coast area of Peary Land cut a sedimentary sequence of Carboniferous, Permian and Cretaceous strata (Håkansson et al., 1981; Higgins et al., 
1981) but fail to cut the Kap Washington Group of volcanics, the base of which is of late Cretaceous age (Brown \& Parsons, 1981; Batten et al., 1981). GGU 53573 (199 Ma) is taken from a dyke of a regional $\mathrm{N}-\mathrm{S}$ swarm that is regarded by Higgins et al. (1981) as the same age as the above mentioned Cretaceous intrusions. In this case the K/Ar date of 199 $\mathrm{Ma}$ is demonstrably too high.

No direct or indirect geological control exists for any of the other dykes reported on here. However all eight samples belong to a distinct chemical suite characterised by exceptionally high titanium, 4 per cent $\mathrm{TiO}_{2}$ on average (Table 1). Persistence of such an unusual magmatic source over the time span implied by the apparent ages (over $200 \mathrm{Ma}$ ) would indeed be remarkable. We suggest that all the dykes sampled are members of the alkaline basalt dyke province described by Soper et al. (1982) that is regarded as Cretaceous in age.

Which, if any, of the Cretaceous age dates reported on here $(130,119,82 \mathrm{Ma})$, or elsewhere (72 and $66 \mathrm{Ma}$ ) might reflect the age of this alkaline magmatism is unknown; likewise it is uncertain if the $\mathrm{K} / \mathrm{Ar}$ dates represent an extended period of Mesozoic dyke emplacement. In this context it is interesting that in both Arctic Canada and Svalbard there is a wide range of Mesozoic $\mathrm{K} / \mathrm{Ar}$ ages on dolerite dykes, some of which at least are considered geologically significant. For example, in Canada the main range is from $180 \mathrm{Ma}$ to $90 \mathrm{Ma}$ with apparently meaningful maxima at about $140 \mathrm{Ma}$ (Jurassic-Cretaceous boundary), $116 \mathrm{Ma}$ (Barremian), and 110 to $102 \mathrm{Ma}$ (Aptian-Albian). Collaborative stratigraphic control is partly available, for example basaltic rocks occur at several levels in Lower Cretaceous rocks and within early Upper Cretaceous beds (Balkwill, 1978). Likewise in Svalbard K/Ar age dates range from $165 \mathrm{Ma}$ to $70 \mathrm{Ma}$ (Gayer et al., 1966; Burov et al., 1977) and two phases of dyke emplacement represented by age maxima at $115 \mathrm{Ma}$ and 105 Ma have been suggested.

\section{Conclusion}

As a batch the K/Ar isotopic age determinations from the North Greenland fold belt are clearly unreliable, and there are insuperable difficulties in the interpretation of the dates as being geologically significant. The samples giving the abnormally high ages are presumably affected by the presence of considerable excess argon. In view of the known regional late Phanerozoic reactivation of the fold belt it seems likely that at least some of this excess argon is secondary, i.e. introduced through migration and incorporation during regional reheating, rather than accumulation in the dykes during 'abnormal' intrusion conditions. Some support for this is perhaps seen in the geographical distribution of the samples (fig. 3), i.e. the youngest $\mathrm{K} / \mathrm{Ar}$ ages $(82,72$ and $66 \mathrm{Ma})$ are from the platform and southern margin of the fold belt, away from the known area of regional tectonic and metamorphic overprinting in northernmost Peary Land. The dykes giving $250 \mathrm{Ma}$ and $220 \mathrm{Ma}$ are from within the Harder Fjord fault zone (Soper et al., 1980; Higgins et al., 1981; Håkansson et al., 1981); a major dislocation zone that was active in as late as Tertiary time and along which redistribution of argon during fault movements might be expected.

\section{References}

Balkwill, H. R. 1978: Evolution of Sverdrup Basin, Arctic Canada. Bull. Am. Assoc. Petrol. Geol. 62, 1004-1028. 
Batten, D. J., Brown, P. E., Dawes, P. R., Higgins, A. K., Koch, B. E., Parsons, I. \& Soper, N. J. 1981: Peralkaline volcanicity on the Eurasia Basin margin. Nature, Lond. 294, 150-152.

Brown, P. E. \& Parsons, I. 1981: The Kap Washington Group volcanics. Rapp. Grønlands geol. Unders. $106,65-68$.

Burov, J. P., Krasil'ščikov, A. A., Firsov, L. V. \& Klubov, B. A. 1976: The age of Spitsbergen dolerites (from isotopic dating). Arbok Nor. Polarinst. 1975, 101-108.

Dawes, P. R. \& Soper, N. J. 1971: Significance of K/Ar age determinations from the northern Peary Land. Rapp. Grønlands geol. Unders. 35, 60-62.

Dawes, P. R. \& Soper, N. J. 1979: Structural and stratigraphic framework of the North Greenland fold belt in Johannes V. Jensen Land, Peary Land. Rapp. Grønlands geol. Unders. 93, 40 pp.

Friderichsen, J. D., Higgins, A. K., Hurst, J. M., Pedersen, S. A. S., Soper, N. J. \& Surlyk, F. 1982: Lithostratigraphic framework of the Upper Proterozoic and Lower Palaeozoic deep water clastic deposits of North Greenland. Rapp. Grønlands geol. Unders. 107, $20 \mathrm{pp}$.

Gayer, R. A., Gee, D. G., Harland, W. B., Miller, J. A., Spall, H. R., Wallis, R. H. \& Winsnes, T. S. 1966: Radiometric age determinations on rocks from Spitsbergen. Skr. Nor. Polarinst. 137, 39 pp.

Håkansson, E., Heinberg, C. \& Stemmerik, L. 1981: The Wandel Sea Basin from Holm Land to Lockwood Ø, eastern North Greenland. Rapp. Grønlands geol. Unders. 106, 47-63.

Håkansson, E. \& Pedersen, S. A. S. 1982: Late Paleozoic to Tertiary tectonic evolution of the continental margin in North Greenland. In Embry, A. F. \& Balkwill, H. C. (edit.) Arctic geology and geophysics. Mem. Can. Soc. Petrol. Geol. 8, 331-348.

Henriksen, N. \& Jepsen, H. F. 1970: K/Ar age determinations on dolerites from southern Peary Land. Rapp. Grønlands geol. Unders. 28, 55-58.

Higgins, A. K., Friderichsen, J. D. \& Soper, N. J. 1981: The North Greenland fold belt between central Johannes V. Jensen Land and eastern Nansen Land. Rapp. Gronlands geol. Unders. 106, 33-45.

Rex, D. C. \& Dodson, M. H. 1970: Improved resolution and precision of argon analyses using an AE1 MS10 mass spectrometer. Eclog. geol. Helv. 63, 275-280.

Soper, N. J., Higgins, A. K. \& Friderichsen, J. D. 1980: The North Greenland fold belt in eastern Johannes V. Jensen Land. Rapp. Grønlands geol. Unders. 99, 89-98.

Soper, N. J., Dawes, P. R. \& Higgins, A. K. 1982: Cretaceous-Tertiary magmatic and tectonic events in North Greenland and the history of adjacent ocean basins. In Dawes, P. R. \& Kerr, J. W. (edit.), Nares Strait and the drift of Greenland: a conflict in plate tectonics. Meddr Grønland, Geosci. 8, 205-220.

D.C.R.,

Department of Earth Sciences,

University of Leeds,

Leeds LS2 9JT,

U.K.
N.J.S.,

Department of Geology, University of Sheffield, Sheffield S1 3JD,

U.K. 